доктор історичних наук, професор, академік НАПН України.

Ректор ДВНЗ «Переяслав-Хмельницький державний педагогічний університет імені Григорія Сковороди»

Dr. Victor Kotsur

Doctor of Historical Sciences, Professor, Academician NAPSU.

Rector of the "Pereyaslav-Khmelnitsky State

Pedagogical University named after Gregory Skovoroda»

\title{
ІСТОРІОГРАФІЯ УКРАЇНСЬКОГО СКАРБОЗНАВСТВА
}

\section{HISTORIOGRAPHY OF THE UKRAINIAN TREASUROLOGY}

\section{Анотація}

У статті розглянуто історіографію вивчення скарбів монет, пов'язаних з історією грошового обігу українських історичних регіонів. Сукупність знань щодо монетних скарбів, а саме: джерелознавча цінність монетних комплексів, їх класифікація, причини тезаврації, топографія знахідок, склад скарбів, скарбові ємності, методологія та джерела дослідження визначається поняттям скарбознавство.

Дефініції поняття «скарб» досить повно та якісно наведені у нумізматичних словниках. Враховуючи те, що нумізматична наука суттєво збагатилася новими знаннями, вважаємо за необхідне внести доповнення у визначення поняття скарбу.

Вивчення та детальний аналіз скарбів $є$ одним із ефективних інструментів в уточненні окремих питань метрології монет, систем їх лічби, скарби тісно пов'язані 3 українським народним фольклором.

У дореволюційній історіографії провідні вітчизняні дослідники приділяли увагу питанню надходження скарбів до збірки мюнц-кабінету Університету Св. Володимира, а також складання топографії знахідок монетних скарбів в окремих історичних регіонах України - Полісся, Волині, Північного Причорномор'я.

У довоєнний період увага вітчизняних нумізматів у фокусі скарбознавства була акцентована головним чином на розширенні уявлень про топографії скарбів, знахідки монет Київської Русі та стародавнього Риму.

Основи вітчизняного скарбознавства та основні аспекти методології наукового вивчення скарбів закладені М.Ф. Котляром. У період незалежності України продовжили наукову фіксацію скарбів та вивчення їх ролі як джерела у вивченні історії грошового обігу українських історичних регіонів. Вагомим джерелом у вивченні скарбознавчих аспектів $\epsilon$ дані архівів, а також ресурсів мережі Інтернет.

Враховуючи той факт, що численна кількість скарбів, що демонструють вже відомі «зрізи» грошового обігу тих чи інших історичних регіонів у різні історичні періоди, вже опублікована і достатньо широко вивчена, подальші дослідження сучасних науковців ми бачимо у вивченні скарбів із таким складом, який відрізняється за структурою від класичних, містить раніше невідомі у складі скарбів монети, уточнює або підкреслює роль монет окремих емітентів у грошовому обігу України та Східної і Центральної Свропи на загал.

\section{Summary}

The article deals with the historiography of the study of treasures of coins connected with the history of monetary circulation of Ukrainian historic regions. The totality of knowledge about the coin treasures, namely: the source value of the coin complexes, their classification, the causes of tezavrasii, topography of finds, the composition of treasures, treasure trove of the methodology and sources of research is determined by the notion of treasury.

The definitions of the concept of treasure are quite complete and qualitatively presented in numismatic dictionaries. Given the fact that the numismatics science has been substantially 
The Ukrainian Numismatic Annual, Issue 1.

enriched with new knowledge, we consider it necessary to supplement the definition of the concept of treasure. In addition to the works of the predecessors of the signs, it should be added that treasures can consist not only of coins, but also of paper money, and other valuables, of scrap of precious metal, etc.

Study and detailed analysis of treasures is one of the effective tools in clarifying certain issues of metrology of coins and their systems, which in previous studies we defined as one of the most important directions of modern studies on numismatics of the Middle Ages in the history of Ukrainian historic lands.

Treasures are closely linked to Ukrainian folklore, endowed with enchantment, mystery, are often spoken or spellbound.

In prerevolutionary historiography, leading domestic researchers paid attention to the issue of treasures' receipt for the collection of St. Volodymyr's University's Münster Cabinet, as illustrated by K. Strashkevich. Also, research focused mainly around the compilation of the topography of finds of coin treasures in some historical regions of Ukraine studied: the findings of Polissya - M.F. Bilyashivsky, Volyn - V.B. Antonovich, Northern Black Sea Region V. Goshkevich.

Numerous references to the finds of treasures are contained in Ukrainian pre-revolutionary newspaper periodicals.

In the prewar period, the attention of domestic numismatists in the focus of the treasury was focused mainly on expanding representations about the topography of treasures, the findings of the coins of Kievan Rus' were fixed by A. Ilyin, the question of the distribution of coins of ancient Rome and their finds - V. Lyaskoronsky.

Attention to the topography of the finds of coin treasures in some historical regions of Ukraine was given to Soviet scientists: the common findings of coins of the $16^{\text {th }}-17^{\text {th }}$ centuries are described by D. Berg, the findings of treasures on the territory of historical Podillya - M. Kotljar, historical Sivershchyna - V. Ryabtsevich, findings Western European early medieval coins published by V. Potin, Roman coins on the territory of the USSR - V. Kropotkin. The treasure of the Roman antoninists from the Crimean peninsula was published by I. Pioro and A. Herzenim, the coins of the Byzantine Kherson - A. Gilevich.

Fundamentals of domestic treasury and the main aspects of the methodology of scientific study of treasures laid by Mykola Kotlyar. One of the sensational cases was the discovery of a whole treasure of coins captured in Kyiv on behalf of Duke Volodymyr Olgerdovich, also investigated by M. F. Kotlyar.

During the period of Ukraine's independence, scholarly fixation of treasures and the study of their role as sources in the study of the history of monetary circulation of Ukrainian historic regions were studied by O. Popelnytska and O. Bakalets.

An important source in the study of treasury aspects is the data archives, as well as Internet resources.

Among the complex finds of coins are known numismatists and certain special finds, or non-standard treasures. Examples of such finds are monist - jewelry made of coins, as well as cases of finds in coins of treasures that are uncharacteristic of the monetary structure of a particular period and region.

Consequently, from the above material, the following conclusions and suggestions can be made. Treasures found on the territory of Ukrainian historic regions are a powerful source of study of the history of money circulation. Attention to the study of treasures was given to both Ukrainian and foreign researchers since the time of the Russian Empire, which emphasizes the high importance and relevance of their study. An impressive array of treasure information includes archival sources, modern digital information Internet resources, newspapers, and more. The study of treasures is reflected not only in popular science-historical intelligence, but also in scientific profile research: scientific reports, descriptions, topographies, complex studies and scientific dissertations. Mint treasures stored in museums' funds are actively introduced into scientific circulation. As for the method of treasury storage in museums, we see the actual development of a modern instruction on the storage and marking of coins in the study and research of treasures.

Taking into account the fact that the numerous treasures showing already known "slices" of monetary circulation of certain historical regions in different historical periods have already been published and are widely studied, further researches of modern scholars we see in the study of 
treasures with a composition that is different based on the structure of the classical, contains previously unknown in the treasure coin, clarifies or emphasizes the role of coins of individual issuers in the monetary circulation of Ukraine and Eastern and Central Europe in total.

Ключові слова: скарб, скарбознавство, тезаврації монет, грошовий обіг, українські землі, джерела вивчення нумізматики, методика нумізматичних досліджень.

Key words: hoard, treasury, thesaurus of coins, money circulation, Ukrainian lands, sources of study of numismatics, methods of numismatic research.

Дефініції поняття «скарб» досить повно та якісно наведені у нумізматичних словниках. Відомий український нумізмат В. Зварич подає таке визначення скарбу: «Деяка сума грошей у вигляді металевих монет, частіше всього у сосуді, зазвичай глиняному, загорнута у тканину, шкіру та ін., захована у землю, у дупло дерева, під фундамент будівлі та ін.» ${ }^{1}$ (переклад 3 рос. - В. К.). Враховуючи те, що $з$ моменту публікації вищезгаданого словника нумізматична наука суттєво збагатилася новими знаннями, вважаємо за необхідне внести доповнення у визначення поняття скарбу. Окрім наведених автором ознак, необхідно додати, що скарби можуть складатися не лише 3 монет, а і з паперових грошей, цінних паперів, інших вартісних речей, 3 лому дорогоцінного металу та ін. Більш стисле, але досить широке за змістом визначення наведено у словнику-довіднику термінології музейництва, складеного Р. Микульчиком, П. Слободяном, Є. Діденко та Т. Раком: «Випадково знайдені цінності, найчастіше - вироби 3 дорогоцінних металів та коштовного каміння» ${ }^{2}$. Дана дефініція визначає будь-які археологічні знахідки, що містять колись заховані цінності. Слід наголосити на тому, що в умовах сьогодення, враховуючи широкий розмах несанкціонованих аматорських археологічних пошуків, недоречним $\epsilon$ вживання прикметника «випадковий», адже поширене сьогодні в Україні явище «чорної» археології передбачає умисний пошук цінностей з використанням точної пошукової техніки, серед знахідок за допомогою якої трапляються і монетні скарби. Проблематику використання матеріалів «чорної» археології ми розглядали у попередньому дослідженні ${ }^{3}$.

Вивчення та детальний аналіз скарбів є одним із ефективних інструментів в уточненні окремих питань метрології монет, систем їх лічби, що в попередніх дослідженнях ми визначали як один із актуальних напрямків сучасних досліджень із нумізматики доби Середньовіччя в історії українських історичних регіонів ${ }^{4}$.

Скарби тісно пов'язані із українським народним фольклором, наділені зачарованістю, таємничістю, нерідко є заговореними чи заклятими. Одні із перших свідчень про незліченні скарби гайдамаків дійшли до нас через усні оповідання, зафіксовані Н. Сементовським ${ }^{5}$, перекази місцевих жителів про скарби острова Хортиці, передані Я. Новицьким ${ }^{6}$.

У дореволюційній історіографії провідні вітчизняні дослідники приділяли увагу питанню надходження скарбів до збірки мюнц-кабінету Університету

\footnotetext{
Зварич В. В. Нумизматический словарь / В. В. Зварич. - Львов: «Вища Школа», 1980. - С. 88.

${ }^{2}$ Микульчик Р. Словник-довідник термінології музейництва / Р. Микульчик, П. Слободян, С. Діденко, Т. Рак // Слово Світ. - № 15. - Львів: «Видавництво Львівської політехніки», 2012. - С. 104.

${ }^{3}$ Kotsur V. Methodological issues of modern numismatic research: materials of «black» archeology and scientific research // Studia I Materialy «Forum Numizmatyczne, Pieniadz I Mennice». - № 1. - Bialystok, 2016. - S. 5-9.

${ }^{4}$ Коцур В. П. Актуальні напрямки та організаційні засади сучасних досліджень середньовічної нумізматики в Україні / В. П. Коцур // Збірник наукових статей «Наукові записки з української історії». - Вип. 33. - ПереяславХмельницький, 2013. - С. 4.

${ }^{5}$ Сементовский Н. М. Запорожская рукопись указывающая в каких именно местах и какие сокрыты клады гайдамаками и местными жителями / Н. М. Сементовский. - Киев: «Типография А. Гаммершмидта», $1857 .-60$ с.

${ }^{6}$ Новицький Я. Острів Хортиця на Дніпрі, його природа, історія, старожитності // Старожитності Південної України. Вип. 1. «150-річчю Я. Новицького присвячується». - Запоріжжя: «Тандем-У», 1997. - С. 46-51.
} 
Св. Володимира, що висвітлено К. Страшкевичем ${ }^{1}$. Також дослідження головним чином сконцентрувались навколо складання топографії знахідок монетних скарбів в окремих історичних регіонах України вивчали: знахідки Полісся М. Ф. Біляшівський ${ }^{2}$, Волині - В.Б. Антонович ${ }^{3}$, Північного Причорномор'я В. Гошкевич ${ }^{4}$.

Численні згадки про знахідки скарбів містяться в українській дореволюційній газетній періодиці. Українським науковцем А.С. Бойко-Гагаріним здійснено критичний аналіз переваг та недоліків використання інформації щодо скарбів 3 газетної періодики, а також виявлені раніше не враховані у топографіях скарбові комплекси монет X - XII століть 5 . Зауважимо, що матеріали дореволюційної газетної періодики містять свідчення і про скарби більш пізніших періодів, зокрема «Кіевская почта» за 1 квітня 1912 року повідомляє про цінну знахідку скарбу монет Візантії у маєтку В. Пуліковського неподалік Десятинної церкви у Києві ${ }^{6}$, про знахідку «старовинних польських монет» (імовірно, ідеться про монети Речі Посполитої В. К.) повідомляє «Кіевское утро» за 25 жовтня 1910 року ${ }^{7} 3$ дореволюційних газет дізнаємось також i про курйозні випадки навколо скарбів та любителів старожитностей - «Житомирская минута» за 26 грудня 1908 року повідомляе про випадок шахрайства і продажу штучно сфабрикованого «скарбу» золотих монет колекціонеру 8 , який вже вдома після купівлі встановив, що всі продані йому монети мідні і не складають матеріальної цінності, про що редакцією додатково повідомлено читачам у випуску наступного дня9. Майже аналогічне шахрайство із продажем мідних монет замість золотих напівімперіалів відмічено в Криму редакцією газети «Терджиманъ» від 25 січня 1905 року ${ }^{10}$.

У довоєнний період увага вітчизняних нумізматів у фокусі скарбознавства була акцентована головним чином на розширенні уявлень про топографії скарбів, знахідки монет Київської Русі, зафіксовані А. А. Ільїним ${ }^{11}$, питання поширення монет давнього Риму та їх знахідок - В.Г. Ляскоронськийм ${ }^{12}$.В українській довоєнній нумізматичній історіографії відомі також і критичні огляди робіт, присвячених скарбовим знахідкам. Так К. Харламповичем в науковому журналі українознавства «Україна» за 1929 рік $^{13}$ опублікований критичний аналіз роботи П. Харламповича, присвяченої знахідкам «празьких» грошей королівства Богемії ${ }^{14}$.

Увагу до топографії знахідок монетних скарбів в окремих історичних регіонах України приділяли радянські вчені: загальні знахідки монет XVI -

\footnotetext{
1 Страшкевич К. Клады, рассмотреные в минц-кабинете университета св. Владимира с 1818 по 1866 гг. / К. Страшкевич // Университетские известия. - 1866. - №10. - С. 1-38; № 11. - С. 1-30; №12. - С. 1-42; 1867. - № 10. C. $1-15$.

${ }^{2}$ Беляшевский Н. Ф. Монетные клады Киевской губернии / Н. Ф. Беляшевский. - Киев, 1889.

${ }^{3}$ Антоновичь В. Б. Археологическая карта Волынской губернии / В. Б. Антоновичь. - Москва: «Типография Г. Лисснера и А. Грешеля», 1900. - 140 с. + карты.

4 Гошкевичь В. И. Клады и древности Херсонской губернии. Книга первая с художественными иллюстрациями / В. И. Гошкевичь. - Херсон: «Типография Юга», 1903. - 171 с. $з$ табл.

${ }^{5}$ Бойко-Гагарин А. С. Находки монет X-XII веков по материалам украинской дореволюционной газетной периодики // Материалы докладов и сообщений III Международная нумизматическая конференция «Эпоха викингов в Восточной Европе в памятниках нумизматики VIII-XI вв.». - 22-24 апреля 2016 года. - Санкт-Петербург, 2016. - С. 397-403.

${ }^{6}$ Клад // Киевская почта. - № 995. - воскресенье, 1 апреля 1912 г. - Киев, 1912. - С. 3.

${ }^{7}$ К находке клада // Киевское утро. - № 69. - 25 октября 1910 г. - Киев, 1910. - С. 2.

${ }^{8}$ Клад // Житомирская минута. - № 1. - пятница 26 декабря 1908 г. - Житомир, 1908. - С. 2.

${ }^{9}$ К заметке о «кладе» // Житомирская минута. - № 2. - суббота 27 декабря 1908 г. - Житомир, 1908. - С. 2.

${ }^{10}$ Мошенничество // Терджиманъ. - № 7 (23). - 25 января 1905 г. (3-го Зиль-Хидже 1322 г.). - Бахчисарай, 1905. - С. 1.

${ }^{11}$ Ильин А. А. Топография кладов древних русских монет Х-XI в. и монет удельного периода / А. А. Ильин. Ленинград, 1924. - 63 с.

12Ляскоронский В. Г. Римская монета в пределах Южной Руси как исторический источник для древнейшего периода русской истории // Известия Историко-филологического института князя Безбородько в Нежине. - Т. XXXIII. Нежин, 1920. - С. 1-16.

${ }^{13}$ Харлампович К. - Науковий журнал українознавства «Україна». - Книга 36. - Київ: «Державне видавництво України», 1929. - С. 147-149.

${ }^{14}$ Харламповіч П. Монэтныя скарбы, знойдзеныя ў Беларусі, у зборах Буларускага дзяржаўнага музэю / П. Харламповічь. - Мінск, 1929. - 343 с.
} 
XVII століття викладені Д. Берг ${ }^{1}$, знахідки скарбів на території історичного Поділля - М. Ф. Котляром ${ }^{2}$, історичної Сіверщини - В. Н. Рябцевичем ${ }^{3}$, знахідки західноєвропейських ранніх середньовічних монет опубліковані В. М. Потіним ${ }^{4}$, римських монет на території СРСР - В. В. Кропоткіним ${ }^{5}$. Скарб римських антонініанів із Кримського півострова опублікований І. С. Піоро та А. Г. Герценим 6 , монет візантійського Херсону - А. Гілевич ${ }^{7}$.

Основи вітчизняного скарбознавства та основні аспекти методології наукового вивчення скарбів закладені М. Ф. Котляром ${ }^{8}$. Сенсаційною колись стала знахідка цілого скарбу монет, карбованих у Києві від імені князя Володимира Ольгердовича, що також досліджені М. Ф. Котляром 9

Збереженню, комплексному науковому вивченню та популяризації монетні скарби піддаються в радянський час у музеях. Музейними зберігачами та науковцями приділяється особлива увага до монетних скарбів, які ретельно описуються і зберігаються цілісно, не порушуючи єдність абсолютно всіх монет та інших предметів, що знаходились у скарбі. Порядок приймання, опису, зберігання, інвентаризації та переміщення переданих до музеїв скарбів детально викладено в Інструкції по обліку та зберіганню музейних цінностей із дорогоцінних металів та дорогоцінних каменів, що знаходяться у державних музеях, складеної ще за часів $\mathrm{CPCP}^{10}$. Враховуючи те, що 3 моменту утвердження згадана інструкція суттєво застаріла і не відображає сучасні вимоги до умов збереження монет, їх маркування та апробації, ми визначаємо високу актуальність та терміновість у необхідності складення та утвердження нової інструкції щодо збереження музейних предметів, зокрема монетних скарбів, затвердженого Міністерством культури України.

Відомі випадки знахідок скарбів, у склад яких не були тезавровані монети, вилучені із грошового обігу в певний часовий період, а колишнім власником заховано цілу колекцію різноманітних монет різних часових періодів та географії країн емітентів. Яскравим прикладом такого скарбу $є$ комплекс, знайдений i опублікований М. С. Стрілець 1989 року під час будівельних робіт у Києві по вулиці Січових Стрільців (в часи знаходження скарбу - вулиця Артема - В.К.), що складався із 109 монет, серед яких присутні монети давньої Греції, Російської та Австро-Угорської імперії, різних країн Свропи та монети Китаю ${ }^{11}$. Ми погоджуємось iз публікатором комплексу, що скарб такого змісту не є характерним для скарбів кінця XIX століття, захованих відповідно до природних причин, i може бути визначений як захована приватна колекція.

${ }^{1}$ Берг Д. Я. Некоторые клады монет XVI - XVII вв., найденные на территории УССР / Д. Я. Берг // Нумизматика и Сфрагистика. - Том. V. - Киев: «Наукова думка», 1974. - С. 105-109.

${ }^{2}$ Котляр М. Ф. Монетні скарби Поділля як історичне джерело / М. Ф. Котляр // Тези доповідей [«V-ої Подільської історико-краєзнавчої конференції»]. - Кам’янець-Подільський, 1980. - С. 151-152.

${ }^{3}$ Рябцевичь В.Н. Монетные клады XVII и первой четверти XVIII в. натерритории Чернигово-Северской земли и Восточной Белоруссии / В. Н. Рябцевичь // Нумизматика и сфрагистика. - Том. І. - Киев: «Издательство Академии наук Украинской ССР», 1963. - С. 152-202.

${ }^{4}$ Потин В.М. Находки западноевропейских монет на территории древней Руси и древнерусские поселения / В. М. Потин // Нумизматика и эпиграфика. - Том. III. - Москва: «Издательство Академии наук СССР», 1962. - С. $183-$ 212.

${ }_{5}^{5}$ Кропоткин В. В. Клады римских монет на территории СССР / В. В. Кропоткин. - Москва: «Издательство Академии наук СССР», 1961. - 134 с.

${ }^{6}$ Пиоро А. С. Клад антонинианов из с. Долинное Крымской области / А. С. Пиоро, А. Г. Герцен // Нумизматика и сфрагистика. - № 5. - Киев: «Наукова думка», 1974. - С. 81-90.

${ }^{7}$ Гилевич А. Клад херсоно-византийских монет из округи Херсонеса / А. Гилевич // Нумизматика и сфрагистика. № 5. - Киев: «Наукова думка», 1974. - С. 91-94.

${ }^{8}$ Котляр М. Ф. Шукачі та дослідники скарбів / М. Ф. Котляр. - К.: «Наукова думка», 1971. - 130 с.

${ }^{9}$ Котляр Н. Ф. Клад монет Владимира Ольгердовича / Н. Ф. Котляр // Нумизматика и эпиграфика. - Том. VIII. Москва: «Наука», 1970. - С. 88-101.

${ }^{10}$ Инструкция по учету и хранению музейных ценностей из драгоценных металлов и драгоценных камней, находящихся в государственных музеях СССР // Приложение к приказу Министерства культуры СССР от «15» декабря 1987 г. № 513. - Москва, 1987. - С. 14-15.

${ }^{11}$ Стрілець М. С. Київський монетний скарб із вул. Артема (нові надходження) / М. С. Стрілець // Тематичний збірник наукових праць «Музей і сучасність». - Київ, 1989. - С. 38-47. 
У період незалежності України продовжили наукову фіксацію скарбів та вивчення їх ролі як джерела у вивченні історії грошового обігу українських історичних регіонів досліджували О. Попельницька ${ }^{1}$ О. Бакалець ${ }^{2}$ та ін.

Окрім питання ефективності використання скарбів у нумізматичних дослідженнях, на окрему увагу заслуговують джерела вивчення самих скарбів та пов'язаних із ними аспектів.

Вагомим джерелом у вивчення скарбознавчих аспектів є дані архівів, роль яких досліджено О. Бєлою ${ }^{3}$. Вченою досліджено інформативність збережених в архівах урядових наказів та законів щодо археологічних та випадкових знахідок скарбів.

Українським ученим В. Орликом підкреслено вагомий інформаційний потенціал WEB-ресурсів у нумізматичних дослідженнях ${ }^{4}$. На прикладі дослідження монет держав Хрестоносців учений детально обгрунтував високу ефективність використання ресурсів Інтернету в дослідженнях у галузі спеціальних історичних дисциплін, що також може бути використано у скарбознавчих дослідженнях. Популярні світові та вітчизняні Інтернет ресурси нерідко містять повідомлення про знахідки скарбів, про їх склад, що суттєво розширює уявлення про топографію відомих знахідок скарбів та збагачує нумізматичну науку численними новими даними, корисними для дослідників.

У період незалежності України увагу до вітчизняних скарбових комплексів окремих регіонів приділено і зарубіжними дослідниками - топографію знахідок монет Боспорського царства опубліковано М. Абрамзоном та Н. Фроловою5. Також білоруським вченим І. Сінчуком було встановлено роль монет князівства Тешин, карбованих від імені Слизавети Лукреції (1625 -1653), шляхом аналізу українських скарбів ${ }^{6}$.

Краєзнавчі науково-популярні регіональні дослідження, основані на аналізі та вивченні скарбів, досліджували: М. Кучинко та 3. Кучинко по скарбах Волині ${ }^{7}$, монетних тезаврацій Черкащини - А. Шостопал ${ }^{8}$, найбільш визначні скарбові знахідки України - Н. Метелкін9 .

Вагомі здобутки вітчизняних науковців у вивченні скарбів узагальнені в історіографії здобутків нумізматичної науки в Україні, складеній Г. Голишем ${ }^{10}$.

Вітчизняними вченими нерідко публікуються в спеціалізованих та науковопопулярних виданнях повідомлення про знахідки скарбів, вивчені та досліджені нові скарби вводяться в науковий обіг. Наведемо приклади таких публікацій,

\footnotetext{
${ }^{1}$ Попельництва О. Нумізматично-речові скарби як історичне джерело (на прикладі скарбу XVI-XVIIстоліття 3 села Старосілля) / О. Попельницька // Збірка наукових праць до 10-ліття заснування відділу спеціальних історичних дисциплін Інституту історії НАН України «Спеціальні історичні дисципліни: питання теорії та методтики». Число 11. - Ч. І. - Київ, 2004. - С. 204-217.

${ }^{2}$ Бакалець О. Монетні скарби як джерело вивчення: автореф. дис. на здобуття наук. ступеня канд. істор. наук: спец. 07.00.06 «Історіографія, джерелознавство та спеціальні історичні дисципліни» / О. Бакалець. - К, 2007. - 15 с.

${ }^{3}$ Бєлая О. Архівні джерела про монетні скарби Києва / О. Бєлая // Археографічний щорічник «Пам’ятки». - Вип. 14. Київ, 2013. - С. 189-194.

${ }^{4}$ Орлик В. M. Інформаційний потенціал WEB-ресурсів у нумізматичних дослідженнях (на прикладі монет держав Хрестоносців) / В.М. Орлик // Матеріали наукової конференції 3 міжнародною участю [«Архівознавчі та джерелознавчі галузі знань: проблеми взаємодії на сучасному етапі»] (14 березня 2013 р., м. Київ). - Київ, 2013. C. $129-133$.

${ }_{5}^{5}$ Абрамзон М. Г. Корпус боспорских кладов античных монет / М. Г. Абрамзон, Н. А. Фролова. - Том. I (1834-2005). Симферополь-Керчь, 2007-2008. - 721 с.

6 Синчук И. И. Оболы Тешина в кладах Украины / И. И. Синчук // Numizmatika. - № 1. - Vilnius: «Lietuvosnacionalinismuziejus», 2000. - S. 53-63.

${ }^{7}$ Кучинко М. Давні та середньовічні скарби Волині / М. Кучинко, З. Кучинко. - Луцьк: «Волинська книга», 2007. $172 \mathrm{c}$.

${ }^{8}$ Шостопал А. В. Скарби Черкащини / А. В. Шостопал. - Черкаси: «Аадрощук П.С.», 2007. - 120 с.

${ }^{9}$ Метелкин Н. В. Клады Украины / Н. В. Метелкин. - Киев: «Антика», 2005. - 112 с.

${ }^{10}$ Голиш Г. Нумізматичні дослідження в сучасній українській історіографії: здобутки, проблеми, перспективи / Г. Голиш // Збірник наукових статей «Наукові записки з української історії». - Вип. 33. - Переяслав-Хмельницький, 2013. - C. 207-214.
} 
розподіливши публікаторів скарбів у порядку від найдавніших монет у складі скарбу. Нумізмати не оминули увагою також і скарбові тезаврації монет Північного Причорномор'я: скарб вотивних монет-дельфінів опублікований польським нумізматом Л. Моравіцкі ${ }^{1}$, монети Золотої Орди (Улусу Джучі) комплексно вивчаються українським нумізматом Ю. Зайончковським, особливий інтерес складають скарби 3 пізніми монетами періоду «Великої замятні» в Орді, опубліковані та вивчені публікатором ${ }^{2}$. Надзвичайно цікавим в історії грошового обігу українських історичних регіонів $\epsilon$ період «празького гроша», публікації щодо знахідок скарбів яких введені в науковий обіг В. Оприском та М. Рожко ${ }^{3}$ Зріз грошового обігу яскраво демонструє скарб монет XVII століття 3 Гадяччини, опублікований В. Лямкіним та В. Шерстюком ${ }^{4}$. Не менш цікаві скарби часів Російської імперії, серед яких на особливу увагу заслуговують скарби, що містять у своєму складі характерні для українських історичних регіонів дукачі - святкові жіночі прикраси із монет, закріплених на коралове намисто, опубліковані Р. Яушевою-Омельянчик ${ }^{5}$ та М. Стрілець ${ }^{6}$.

Серед комплексних знахідок монет нумізматам відомі і певні особливі знахідки, або нестандартні скарби. Прикладами таких знахідок є мониста прикраси, виконані із монет, а також випадки знахідок у складі скарбів монет, нехарактерних для структури грошового обігу того чи іншого періоду та регіону. У вітчизняній нумізматичній історіографії подібні знахідки намист та гаманця монет XVII століття разом із монетою Римської імперії зафіксовані А. Бойко-Гагаріним ${ }^{7}$ та К. Мизгіним ${ }^{8}$.

Нерідко скарбові матеріали дозволяють встановити роль монет окремих емітентів в грошовому обігу. Так, українським ученим В. Орликом проаналізовано та встановлено роль монет Тевтонського Ордену в Пруссії на території українських історичних регіонів, що здійснено шляхом комплексного дослідження: складення топографії скарбових та одиничних знахідок (та їх аналізу) на території сучасної України ${ }^{9}$, а також наявності вищезгаданих монет у скарбах, що зберігаються в музейних колекціях з суттєвими уточненнями щодо історії їх потрапляння, що

${ }^{1}$ MorawieckiL. Skarb «delfinow» zNikolajewa / L. Morawiecki // Матеріали конференції [«Грошовий обіг і банківська справа в Україні: минуле та сучасність»] (Львів, 14-15 травня 2005 р.). - Львів, 2005. - С. 9-15.

айончковский Ю. В. Клад джучидских дангов XV века с берега реки Северский Донец / Ю. В. Зайончковский // Русь, Литва, Орда в памятниках нумизматики и сфрагистики. - Вып. 1. - Минск: «Рифтур Принт», 2015. - С. 226-241.

${ }^{3}$ Оприск. В. Скарб срібних монет з вул. Клепарківської у м. Львові / В. Оприск, М. Рожко // Матеріали і дослідження 3 археології Прикарпаття і Волині. - Вип. 12. - Львів, 2008. - С. 393-406.

4 Лямкін В. Невеликий монетний скарб середини XVII ст. з Гадяччини / В. Лямкін, В. Шерстюк // Збірник наукових праць «Нові дослідження пам’яток козацької доби в Україні». - Вип. 20. - Частина ІІ. - Київ: «УТОПІК», 2011. C. $17-21$.

5 Яушева-Омельянчик Р. М. Скарб з с. Карапиші (з досвіду ідентифікації в НМІУ) / Р. М. Яушева-Омельянчик // Матеріали наукової конференції, присвяченої пам'яті видатного українського археолога і поета Б. М. Мозолевського (1936-1993) [«Музейні читання»] (Музей історичних коштовностей, лютий 1996 р.). -Київ, 1996. - С. 26-28.

${ }^{6}$ Стрілець М. С. Лебединський монетно-речовий скарб - сенсаційна знахідка 1996 року / М. С. Стрілець // Матеріали наукової конференції Музею історичних коштовностей України - філіалу Національного музею історії України [«Музейні читання»] (м. Київ, 17-18 грудня 1996 р.). - Київ, 1996. - С. 62-66.

7 Бойко-Гагарін А.С. Намисто із шестигрошовиками, карбованими на львівському монетному дворі, найдене у Вінницькій області / А. С. Бойко-Гагарін // Львівські нумізматичні записки. - № 10. - 2013. - Львів, 2014. - С. 48-49.

${ }^{8}$ Бойко-Гагарин А.Кошелек полуторных грошей Сигизмунда III с денарием Тита из Житомирской области / А. БойкоГагарин, К. Мызгин// Вісник Харківського національного університету ім. В.Н. Каразіна. - Серія «Історія». Вип. 48. - № 1117. - Харків, 2014. - С. 240-247.

9 Орлик В. М. Монет государства Тевтонского Ордена в Пруссии в составе денежных и денежно-вещевых кладов, найденных на территории Украины / В. М. Орлик // Збірник наукових статей «Наукові записки з української історії». - Вип. 33. - Переяслав-Хмельницький, 2013. - С. 39-45; ; Idem. Coins of the Teutonic Order contained in the hoard found in the suburbs of the city of Dubno of Rovenska region in march // Pruthenia, X, Olsztyn 2015, s.105-116; Idem. A Coin Hoard of Pre-Reform Shillings of the Grand Master Michael Küchmeister von Sternberg Found in Chernihivschyna. Acta Archaeologica Lodziensia, 2016. 62, 93-97; Idem. Rzadki wariant szeląga Zakonu Krzyżackiego z Teofipolskiego skarbu Biuletyn Numizmatyczny 20174 (388) s.258-263. 
сприяло подальшому розвитку вивчення торговельних зв'язків із державами Західної Європи ${ }^{1}$.

Сьогодні у музейних колекціях зберігається велика кількість скарбів, що регулярно вивчаються та публікуються. Наведемо прикладі деяких із них. Багатою збереженими монетними скарбами є збірка Національного музею історії України, найвідоміші скарби введені до наукового обігу та ретельно проаналізовані Л. Строковою ${ }^{2}$, 3. Зразюк ${ }^{3}$ та Б. Гарбузом та Н. Стрижаковою ${ }^{4}$, надходження скарбів до збірки висвітлено у історії діяльності мюнц-кабінету Університету Св. Володимира Р. Яушевою-Омелянчик 5 . Раїсою Михайлівною ЯушевоюОмельянчик також детально вивчено скарбові матеріали Музею історії міста Києва ${ }^{6}$. Про скарб срібних московських копійок із дроту у збірці Дніпропетровського історичного музею повідомила В. Голубіцька ${ }^{7}$, середньовічні скарби зі збірки Львівського історичного музею вивчала Є. Козловська ${ }^{8}$, Національного історикокультурного заповідника «Чигирин» - Я. Діденко ${ }^{9}$ та О. Маламуж ${ }^{10}$, унікальні скарби монет Кримського ханства та генуезьких консулів у Кафі 3 фондів Бахчисарайського заповідника опубліковані Р. Алієвим ${ }^{11}$, скарби Хмельницького обласного краєзнавчого музею досліджені К. Поворознюк ${ }^{12}$.

Значення скарбів та їх аналіз у дослідженні торговельно-економічних зв'язків в українських історичних регіонах протягом минулих епох досліджували українські вчені С. Климовський ${ }^{13}$ та Г. Козубовський ${ }^{14}$.

Особливо важливими є такі скарби, аналіз складу монет, місця знахідки на топографічній карті та час тезаврації дозволили внести важливі доповнення у наукові знання, дозволили уточнити старі висновки або ввести в науковий обіг принципово нові дані. Надзвичайно актуальними на сьогоднішній день у вітчизняній нумізматиці $є$ питання місцевого грошового обігу, серед яких аспекти нанесення литовських контрамарок на срібні монети Золотої Орди (датування та місце проведення надкарбування) та вивчення питання карбування монет козацькими

\footnotetext{
${ }^{1}$ Орлик В. М. Нумизматические свидетельства торговых связей южноруских земель Великого княжества Литовского с городами государства Тевтонского ордена в Пруссии / В. М. Орлик //Mokslostraipsnių rinkinys «Numizmatikosrinkiniai: istorinėsLietuvosirsujasusijusių šalių paveldas». -Vilnius, 2015. - S. 249-258.

2 Строкова Л. В. Василицький скарб з Черкащини із зібранні НМІ України та його філіалу - Музею історичних коштовностей України / Л.В.Строкова // Матеріали ювілейної міжнародної науково-практичної конференції [«Музей на рубежі епох: минуле, сьогодення, перспективи»]. - Київ, 1999. - С. 75-76.

3 Зразюк 3. О. Монетні скарби першої половини XVII ст. 3 території Правобережної України (сучасна територія Київської та Житомирської області) / З. О. Зразюк // Тематичний збірник наукових праць [«Національному музею історії України - 110»]. - Ч. 1. - Київ, 2009. - С. 158-168.

${ }^{4}$ Гарбуз Б. Польские монеты в Национальном музее истории Украины (история и стан коллекции) / Б. Гарбуз, Н. Стрижакова // MaterialyzIMiedzynarodowejKonferencjiNumizmatycznej [«Bilorus, Litwa, Polska, Ukraina»] (2022.X.1994, Suprasl). - Warszawa, 1996. - S. 21-30.

5 Яушева-Омельянчик Р. М. Київський мюнц-кабінет у 1844-1864 роках / Р. М. Яушева-Омельянчик // Тематичний збірник наукових праць [«Від першовитоків до сьогодення: із історії формування колекції музею»]. - Київ, 1995. C. $174-188$.

6 Яушева-Омельянчик Р. М. Монетні скарби музею / Р. М. Яушева-Омельянчик // Матеріали щорічної науковопрактичної конференції [«Київ і кияни»]. - Вип. 2. - Київ: «Кий», 2002. - С. 95-96.

${ }^{7}$ Голубицкая А. А. Старинные монеты в коллекции ДИМ / А. А. Голубицкая // Доповіді та повідомлення наукової конференції до Міжнародного дня музеїв [«Музей і майбутнє»]. - Дніпропетровськ: «Поліграфіст», 1998. - С. 55-59.

${ }^{8}$ Козловская Е. И. Нумизматическая коллекция Львовского исторического музея / Е. И. Козловская // Нумизматика и сфрагистика. - № 2. - Киев: «Наукова думка», 1965. - С. 152-154.

9 Діденко Я. Л. Середньовічні скарби в фондовому зібранні Національного історико-культурного заповідника «Чигирин» / Я. Л. Діденко // Могилянські читання «Доля музейних зібрань». - Частина 2. - Київ, 2006. - С. 43-48.

10 Маламуж О. Скарб монет XVIIст. (із фондів НIКЗ «Чигирин») / О. Маламуж // Збірка наукових статей «Нові дослідження пам'яток козацької доби в Україні». - Вип. 9. - Київ, 2000. - С. 74-81.

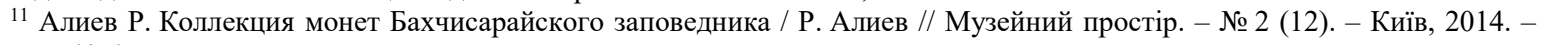
C. 43-45.

12 Поворознюк К. Скарби монет XVI ст. 3 фондів Хмельницького обласного краєзнавчого музею / К. Поворознюк // Збірка наукових праць «Нові дослідження пам’яток козацької доби в Україні». - Вип. 19. - Київ, 2010. - С. 114-117.

${ }^{13}$ Климовский С. И. Вещевые клады ХІІ - ХІІІ как индикатор денежного обращения Южной Руси / С. И. Климовский // Сугдейский сборник. - Вып. 2. - Киев-Судак, 2005. - С. 145-154.

14 Козубовський Г. А. Дані нумізматики про торгівельні шляхи в Україні в середині XIVcт. / Г. А. Козубовський // Археологія. - № 3. - Київ, 2012. - С. 75-82.
} 
гетьманами потребують особливої уваги. Уточнити датування нанесення контрамарок типу «Колюмни» на пізні джучидські данги дозволив комплексний аналіз скарбу, знайденого неподалік містечка Гнівань Вінницької області, здійснений Д. Гулецьким та Ю. Зайончковським ${ }^{1}$. Поєднавши зусилля в науковій роботі спільно з К. Срмаліцькою, автори також провели дослідження окремих монет скарбу із використанням сучасних точних методів вимірювання - визначення складу сплаву поверхні металу методом рентгено-флуорисцентного аналізу (РФА) 2 .

Вагоме значення у нумізматичних дослідженнях на сучасному етапі складає вивчення аспекту фальшування грошей в минулому. Увага дослідників підробки монет в українських історичних регіонах у другій половині XVII століття загострена навколо припущень щодо карбування монет на підпільній монетарні неподалік

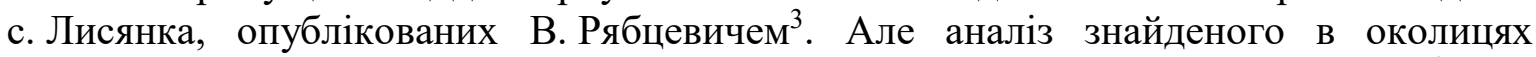
Лисянки скарбу у 1960 році, опублікованого Р. Яушевою-Омельянчик ${ }^{4}$, не підтверджує достовірного існування цього монетного двору, адже не містить жодної монети, характерної для окремої групи локальних імітацій монет. Досліджуючи питання можливості карбування підробних монет від імені гетьмана Богдана Хмельницького (1648 - 1657), проаналізувавши вміст фальшивих монет в скарбах другої половини XVII століття, український науковець А. Бойко-Гагарін дійшов висновку щодо відсутності окремої гетьманської емісії, окресливши перспективи іiі подальшого пошуку ${ }^{5}$. У фокусі досліджень фальшування монет на території українських історичних регіонів надзвичайно цікавим є скарб, знайдений у 1943 році в околицях Луцька, що повністю складався із фальшивих потрійних денаріїв польського короля Владислава Ягайла (1386 - 1434), що опублікований Т. Кальковскі ${ }^{6}$. Згідно зі спостереженнями дослідника Андрія Бойка-Гагаріна у скарбових комплексах, знайдених на території Центральної та Східної Європи, частка фальшивих монет в середньому коливається на рівні $1-2 \%{ }^{7}$.

Отже, із викладеного вище матеріалу можна зробити такі висновки та пропозиції. Скарби, знайдені на території українських історичних регіонів, $\epsilon$ вагомим джерелом вивчення історії грошового обігу. Увагу до вивчення скарбів приділяли як українські, так і зарубіжні дослідники ще з часів Російської імперії, що підкреслює високу важливість та актуальність їх вивчення. Вагомий масив інформації щодо скарбів містять архівні джерела, сучасні цифрові інформаційні Інтернет-ресурси, газетні видання тощо. Вивчення скарбів відображено не лише в науково-популярних історичних розвідках, а і в наукових профільних дослідженнях: наукових повідомленнях, описах, топографіях, комплексних дослідженнях та наукових дисертаціях. Активно вводяться до наукового обігу монетні скарби, що зберігаються у фондах музеїв. Відносно методики зберігання скарбів у музеях ми вважаємо актуальною і необхідною розробку сучасної інструкції щодо зберігання та маркування монет для вивчення та наукового опрацювання скарбів.

${ }^{1}$ Гулецкий Д. Гниваньский клад начала 2-й четверти XV века / Д. Гулецкий, Ю. Зайончковский // Русь, Литва, Орда в памятниках нумизматики и сфрагистики. - Вып. 1. - Минск: «Рифтур Принт», 2015. - С. 163-207.

${ }^{2}$ Гулецкий Д. Состояние металла монет Гниваньского клада / Д. Гулецкий, К. Ермалицкая // Русь, Литва, Орда в памятниках нумизматики и сфрагистики. - Вып. 1. - Минск: «Рифтур Принт», 2015. - С. 208-225.

${ }^{3}$ Рябцевич В.Н. «Лысянковский и «Полтавский», Путивльский и Севский монетные дворы» / В. Н. Рябцевичь // Materialy z III Miedzynarodowej konferencji Numizmatycznej ["Mennice Miedzy Baltykiem a morzem Czarnym - wspolnota dziejow"] (10-12.IX.1998.). - Warszawa, 1998. - S. 175-186.

${ }^{4}$ Яушева-Омельянчик Р. М. Лисянський скарб монет (знахідка 1960 р.) // Тези доповідей наукової конференції Музею історичних коштовностей України - філіалу Національного музею історії України [«Музейні читання»] (м. Київ, грудень 1994). - Київ, 1996. - С. 12-15.

5 Бойко-Гагарин А.С. К вопросу о возможности чеканки гетманом Богданом Хмельницким фальшивых монет / А. С. Бойко-Гагарин // Матеріали Всеукраїнської наукової конференції 3 нагоди 419-річчя від дня народження гетьмана Богдана Хмельницького [«VIII Богданівські читання»]. - Черкаси, 2014 - С. 118-122.

${ }^{6}$ Kalkowski T. Tysiąc lat monety Polskiej / T. Kalkowski. - Krakow, 1974. - S. 106.

${ }^{7}$ Бойко-Гагарин А.С. Фальшивомонетничество в Центральной и Восточной Европе в эпоху Средневековья и раннего Нового времени. - Киев: «Украинская конфедерация журналистов», 2017. - С. 368. 
Враховуючи той факт, що численна кількість скарбів, що демонструють вже відомі «зрізи» грошового обігу тих чи інших історичних регіонів у різні історичні періоди вже опублікована і достатньо широко вивчена, подальші дослідження сучасних науковців ми бачимо у вивченні скарбів із таким складом, який відрізняється за структурою від класичних, містить раніше невідомі у складі скарбів монети, уточнює або підкреслює роль монет окремих емітентів у грошовому обігу України та Східної і Центральної Європи загалом.

У дослідженні скарбознавства українських історичних регіонів ми бачимо такі перспективи:

- Акцентування уваги на тих скарбах, які порівняно із аналогічними скарбами із відомим складом, містять раніше неопубліковані монети, рідкісні емісії.

- Шляхом детального аналізу скарбів дослідити роль окремих монет у грошовому обігу, зокрема: монет князівства Молдавії, Османської імперії, республіки Рагуза (Дубровнік), золотих монет індійських султанатів, монет Анатолійських Бейліків, Тевтонського ордену, монет королівства Угорщини та багатьох інших. скарбів.

- Дослідження особливостей скарбової кераміки та вмістилищ монетних

- Аналіз потрапляння до скарбів фальшивих монет того часу, їх частку у відомих скарбах, окрему увагу приділивши скарбам, що повністю або переважно складаються з фальшивих монет минулого.

- Введення до наукового обігу скарбів, що зберігаються у фондах державних та приватних музеїв, вивчення історії потрапляння скарбів до державних музеїв України, їх походження та історію вивчення.

- Вивчення та узагальнення скарбів, що були знайдені на території українських історичних регіонів, але на сьогоднішній день зберігаються у музеях за кордоном - в Польщі, Білорусі та Російській Федерації.

- Складання доповненої розширеної топографії знахідок скарбів в сучасних межах України монет всіх історичних періодів, окрему увагу приділивши регіонам історичної Бессарабії, Слобожанщини та Степу.

\section{Використані джерела}

1. Клад // Киевская почта. - № 995. - воскресенье, 1 апреля 1912 г. - Киев, 1912. - С. 3.

2. К находке клада // Киевское утро. - № 69. - 25 октября 1910 г. - Киев, 1910. - С. 2.

3. Клад // Житомирская минута. - № 1. - пятница 26 декабря 1908 г. - Житомир, 1908. C. 2.

4. К заметке о «кладе» // Житомирская минута. - № 2. - суббота 27 декабря 1908 г. Житомир, 1908. - С. 2.

5. Мошенничество // Терджиманъ. - № 7 (23). - 25 января 1905 г. (3-го Зиль-Хидже 1322 г.). - Бахчисарай, 1905. - С. 1.

\section{Використана література}

6. Kalkowski T. Tysiąc lat monety Polskiej / T. Kalkowski. - Krakow, 1974. - S. 106.

7. KotsurV. Methodological issues of modern numismatic research: materials of «black» archeology and scientific research // Studia I Materialy «Forum Numizmatyczne, Pieniadz I Mennice». - № 1. - Bialystok, 2016. - S. 5-9.

8. KotsurV. Methodological issues of modern numismatic research: materials of «black» archeology and scientific research // Studia I Materialy «Forum Numizmatyczne, Pieniadz I Mennice». - № 1. - Bialystok, 2016. - S. 5-9.

9. MorawieckiL. Skarb «delfinow» zNikolajewa / L. Morawiecki // Матеріали конференції [«Грошовий обіг і банківська справа в Україні: минуле та сучасність»] (Львів, 14-15 травня 2005 р.). - Львів, 2005. - С. 9-15. 
10. Orlyk W. Coins of the Teutonic Order contained in the hoard found in the suburbs of the city of Dubno of Rovenska region in march // Pruthenia, X, Olsztyn 2015, s.105-116.

11. Orlyk V. A Coin Hoard of Pre-Reform Shillings of the Grand Master Michael Küchmeister von Sternberg Found in Chernihivschyna. Acta Archaeologica Lodziensia, 2016. 62, p.93-97.

12. Orłyk W. Rzadki wariant szeląga Zakonu Krzyżackiego z Teofipolskiego skarbu Biuletyn Numizmatyczny. 2017. 4 (388) s.258-263.

13. Абрамзон М. Г. Корпус боспорских кладов античных монет / М.Г. Абрамзон, Н. А. Фролова. - Том. I (1834-2005). - Симферополь-Керчь, 2007-2008. - 721 с.

14. Алиев Р. Коллекция монет Бахчисарайского заповедника / Р. Алиев // Музейний простір. - № 2 (12). - Київ, 2014. - С. 43-45.

15. Антоновичь В.Б. Археологическая карта Волынской губернии / В.Б. Антоновичь. Москва: «Типография Г. Лисснера и А. Грешеля», 1900. - 140 с. + карты.

16. Бакалець О. Монетні скарби як джерело вивчення: автореф. дис. на здобуття наук. ступеня канд. істор. наук: спец. 07.00.06 «Історіографія, джерелознавство та спеціальні історичні дисципліни» / О. Бакалець. - К, 2007. - 15 с.

17. Беляшевский Н. Ф. Монетные клады Киевской губернии / Н. Ф. Беляшевский. - Киев, 1889.

18. Берг Д. Я. Некоторые клады монет XVI - XVII вв., найденные на территории УССР / Д. Я. Берг // Нумизматика и Сфрагистика. - Том. V. - Киев: «Наукова думка», 1974. C. 105-109.

19. Бєлая О. Архівні джерела про монетні скарби Києва / О. Бєлая // Археографічний щорічник «Пам'ятки». - Вип. 14. - Київ, 2013. - С. 189-194.

20. Бойко-Гагарин А.Кошелек полуторных грошей Сигизмунда III с денарием Тита из Житомирской области / А. Бойко-Гагарин, К. Мызгин// Вісник Харківського національного університету ім. В.Н. Каразіна. - Серія «Історія». - Вип. 48. - № 1117. Харків, 2014. - С. 240-247.

21. Бойко-Гагарин А. С. К вопросу о возможности чеканки гетманом Богданом Хмельницким фальшивых монет / А. С. Бойко-Гагарин // Матеріали Всеукраїнської наукової конференції з нагоди 419-річчя від дня народження гетьмана Богдана Хмельницького [«VIII Богданівські читання»]. - Черкаси, 2014 - C. 118-122.

22. Бойко-Гагарин А. С. Находки монет X-XII веков по материалам украинской дореволюционной газетной периодики // Материалы докладов и сообщений III Международная нумизматическая конференция «Эпоха викингов в Восточной Европе в памятниках нумизматики VIII-XI вв.». - 22-24 апреля 2016 года. - Санкт-Петербург, 2016. - С. 397-403.

23. Бойко-Гагарін А.С. Намисто із шестигрошовиками, карбованими на львівському монетному дворі, найдене у Вінницькій області / А. С. Бойко-Гагарін // Львівські нумізматичні записки. - № 10. - 2013. - Львів, 2014. - С. 48-49.

24. Бойко-Гагарин А.С. Фальшивомонетничество в Центральной и Восточной Европе в эпоху Средневековья и раннего Нового времени. - Киев: «Украинская конфедерация журналистов», 2017. - 560 с.

25. Гарбуз Б. Польские монеты в Национальном музее истории Украины (история и стан коллекции) / Б. Гарбуз, Н. Стрижакова // Materialyz IMiedzynarodowej Konferencji Numizmatycznej [«Bilorus, Litwa, Polska, Ukraina»] (20-22.X.1994, Suprasl). - Warszawa, 1996. - S. 21-30.

26. Гилевич А. Клад херсоно-византийских монет из округи Херсонеса / А. Гилевич // Нумизматика и сфрагистика. - № 5. - Киев: «Наукова думка», 1974. - С. 91-94.

27. Голиш Г. Нумізматичні дослідження в сучасній українській історіографії: здобутки, проблеми, перспективи / Г. Голиш // Збірник наукових статей «Наукові записки 3 української історії». - Вип. 33. - Переяслав-Хмельницький, 2013. - С. 207-214.

28. Голубицкая А. А. Старинные монеты в коллекции ДИМ / А. А. Голубицкая // Доповіді та повідомлення наукової конференції до Міжнародного дня музеїв [«Музей i майбутнє»]. - Дніпропетровськ: «Поліграфіст», 1998. - С. 55-59.

29. Гошкевичь В. И. Клады и древности Херсонской губернии. Книга первая с художественными иллюстрациями / В. И. Гошкевичь. - Херсон: «Типография Юга», 1903. - 171 с. $з$ табл. 
30. Гулецкий Д. Гниваньский клад начала 2-й четверти XV века / Д. Гулецкий, Ю. Зайончковский // Русь, Литва, Орда в памятниках нумизматики и сфрагистики. Вып. 1. - Минск: «Рифтур Принт», 2015. - С. 163-207.

31. Гулецкий Д. Состояние металла монет Гниваньского клада / Д. Гулецкий, К. Ермалицкая // Русь, Литва, Орда в памятниках нумизматики и сфрагистики. Вып. 1. - Минск: «Рифтур Принт», 2015. - С. 208-225.

32. Діденко Я. Л. Середньовічні скарби в фондовому зібранні Національного історикокультурного заповідника «Чигирин» / Я. Л. Діденко // Могилянські читання «Доля музейних зібрань». - Частина 2. - Київ, 2006. - С. 43-48.

33. Зайончковский Ю. В. Клад джучидских дангов XV века с берега реки Северский Донец/ Ю. В. Зайончковский // Русь, Литва, Орда в памятниках нумизматики и сфрагистики. Вып. 1. - Минск: «Рифтур Принт», 2015. - С. 226-241.

34. Зварич В. В. Нумизматический словарь / В. В. Зварич. - Львов: «Вища Школа», 1980. C. 88.

35. Зразюк 3. О. Монетні скарби першої половини XVII ст. 3 території Правобережної України (сучасна територія Київської та Житомирської області) / З. О. Зразюк // Тематичний збірник наукових праць [«Національному музею історії України - 110»]. Ч. 1. - Київ, 2009. - С. 158-168.

36. Ильин А. А. Топография кладов древних русских монет X-XI в. и монет удельного периода / А. А. Ильин. - Ленинград, 1924. - 63 с.

37. Инструкция по учету и хранению музейных ценностей из драгоценных металлов и драгоценных камней, находящихся в государственных музеях СССР // Приложение к приказу Министерства культуры СССР от «15» декабря 1987 г. № 513. - Москва, 1987. - С. 14-15.

38. Климовский С. И. Вещевые клады XII - XIII как индикатор денежного обращения Южной Руси / С. И. Климовский // Сугдейский сборник. - Вып. 2. - Киев-Судак, 2005. С. 145-154.

39. Козловская Е. И. Нумизматическая коллекция Львовского исторического музея / Е. И. Козловская // Нумизматика и сфрагистика. - № 2. - Киев: «Наукова думка», 1965. - С. 152-154.

40. Козубовський Г. А. Дані нумізматики про торгівельні шляхи в Україні в середині XIVст. / Г. А. Козубовський // Археологія. - № 3. - Київ, 2012. - С. 75-82.

41. Котляр М. Ф. Монетні скарби Поділля як історичне джерело / М. Ф. Котляр // Тези доповідей [«V-ої Подільської історико-краєзнавчої конференції»]. - Кам’янецьПодільський, 1980. - С. 151-152.

42. Котляр М. Ф. Шукачі та дослідники скарбів / М. Ф. Котляр. - К.: «Наукова думка», 1971. $-130 \mathrm{c}$.

43. Котляр Н. Ф. Клад монет Владимира Ольгердовича / Н. Ф. Котляр // Нумизматика и эпиграфика. - Том. VIII. - Москва: «Наука», 1970. - С. 88-101.

44. Коцур В. П. Актуальні напрямки та організаційні засади сучасних досліджень середньовічної нумізматики в Україні / В. П. Коцур // Збірник наукових статей «Наукові записки з української історії». - Вип. 33. - Переяслав-Хмельницький, 2013. - С. 4.

45. Кропоткин В.В.Клады римских монет на территории СССР / В. В. Кропоткин. Москва: «Издательство Академии наук СССР», 1961. - 134 с.

46. Кучинко М. Давні та середньовічні скарби Волині / М. Кучинко, З. Кучинко. - Луцьк: «Волинська книга», 2007. - 172 с.

47. Лямкін В. Невеликий монетний скарб середини XVII ст. 3 Гадяччини / В. Лямкін, В. Шерстюк // Збірник наукових праць «Нові дослідження пам'яток козацької доби в Україні». - Вип. 20. - Частина II. - Київ: «УТОПІК», 2011. - С. 17-21.

48. Ляскоронский В. Г. Римская монета в пределах Южной Руси как исторический источник для древнейшего периода русской истории // Известия Историкофилологического института князя Безбородько в Нежине. - Т. XXXIII. - Нежин, 1920. C. 1-16.

49. Маламуж О. Скарб монет XVIIcт. (із фондів НIКЗ «Чигирин») / О. Маламуж // Збірка наукових статей «Нові дослідження пам'яток козацької доби в Україні». - Вип. 9. Київ, 2000. - С. 74-81. 
50. Метелкин Н. В. Клады Украины / Н. В. Метелкин. - Киев: «Антика», 2005. - 112 с.

51. Микульчик Р. Словник-довідник термінології музейництва / Р. Микульчик, П. Слободян, Є. Діденко, Т. Рак // Слово Світ. - № 15. - Львів: «Видавництво Львівської політехніки», 2012. - С. 104.

52. Микульчик Р. Словник-довідник термінології музейництва / Р. Микульчик, П. Слободян, С. Діденко, Т. Рак // Слово Світ. - № 15. - Львів: «Видавництво Львівської політехніки», 2012. - С. 104.

53. Новицький Я. Острів Хортиця на Дніпрі, його природа, історія, старожитності // Старожитності Південної України. - Вип. 1. «150-річчю Я. Новицького присвячується». - Запоріжжя: «Тандем-У», 1997. - С. 46-51.

54. Оприск. В. Скарб срібних монет 3 вул. Клепарківської у м. Львові / В. Оприск, М. Рожко // Матеріали і дослідження з археології Прикарпаття і Волині. - Вип. 12. Львів, 2008. - С. 393-406.

55. Орлик В. М. Інформаційний потенціал WEB-ресурсів у нумізматичних дослідженнях (на прикладі монет держав Хрестоносців) / В. М. Орлик // Матеріали наукової конференції з міжнародною участю [«Архівознавчі та джерелознавчі галузі знань: проблеми взаємодії на сучасному етапі»] (14 березня 2013 р., м. Київ). - Київ, 2013. C. $129-133$.

56. Орлик В. М. Монет государства Тевтонского Ордена в Пруссии в составе денежных и денежно-вещевых кладов, найденных на территории Украины / В. М. Орлик // Збірник наукових статей «Наукові записки з української історії». - Вип. 33. - ПереяславХмельницький, 2013. - С. 39-45.

57. Орлик В. М. Нумизматические свидетельства торговых связей южноруских земель Великого княжества Литовского с городами государства Тевтонского ордена в Пруссии / В. М. Орлик // Mokslostraipsniu rinkinys «Numizmatikosrinkiniai: istorinès Lietuvosirsujasusijusių šaliu paveldas». - Vilnius, 2015. - S. 249-258.

58. Пиоро А. С. Клад антонинианов из с. Долинное Крымской области / А. С. Пиоро, А. Г. Герцен // Нумизматика и сфрагистика. - № 5. - Киев: «Наукова думка», 1974. C. 81-90.

59. Поворознюк К. Скарби монет XVI ст. $з$ фондів Хмельницького обласного краєзнавчого музею / К. Поворознюк // Збірка наукових праць «Нові дослідження пам’яток козацької доби в Україні». - Вип. 19. - Київ, 2010. - С. 114-117.

60. Попельництва О. Нумізматично-речові скарби як історичне джерело (на прикладі скарбу XVI-XVII століття з села Старосілля) / О. Попельницька // Збірка наукових праць до 10-ліття заснування відділу спеціальних історичних дисциплін Інституту історії НАН України «Спеціальні історичні дисципліни: питання теорії та методтики». - Число 11. Ч. І. - Київ, 2004. - С. 204-217.

61. Потин В.М. Находки западноевропейских монет на территории древней Руси и древнерусские поселения / В. М. Потин // Нумизматика и эпиграфика. - Том. III. Москва: «Издательство Академии наук СССР», 1962. - С. 183-212.

62. Рябцевич В.Н. «Лысянковский и «Полтавский», Путивльский и Севский монетные дворы» / В. Н. Рябцевичь // Materialy z III Miedzynarodowej konferencji Numizmatycznej ["Mennice Miedzy Baltykiem a morzem Czarnym - wspolnota dziejow"] (10-12.IX.1998.). Warszawa, 1998. - S. 175-186.

63. Рябцевичь В.Н. Монетные клады XVII и первой четверти XVIII в. натерритории Чернигово-Северской земли и Восточной Белоруссии / В. Н. Рябцевичь // Нумизматика и сфрагистика. - Том. І. - Киев: «Издательство Академии наук Украинской ССР», 1963. - C. 152-202.

64. Сементовский Н. М. Запорожская рукопись указывающая в каких именно местах и какие сокрыты клады гайдамаками и местными жителями / Н. М. Сементовский. - Киев: «Типография А. Гаммершмидта», 1857. - 60 с.

65. Синчук И. И. Оболы Тешина в кладах Украины / И. И. Синчук // Numizmatika. - № 1. Vilnius: «Lietuvosnacionalinismuziejus», 2000. - S. 53-63.

66. Страшкевич К. Клады, рассмотреные в минц-кабинете университета св. Владимира с 1818 по 1866 гг. / К. Страшкевич // Университетские известия. - 1866. - №10. - С. 1-38; № 11. - C. 1-30; №12. - C. 1-42; 1867. - №10. - C. 1-15. 
67. Стрілець М.С. Київський монетний скарб із вул. Артема (нові надходження) / М. С. Стрілець // Тематичний збірник наукових праць «Музей і сучасність». - Київ, 1989. - C. 38-47.

68. Стрілець М. С. Лебединський монетно-речовий скарб - сенсаційна знахідка 1996 року / М. С. Стрілець // Матеріали наукової конференції Музею історичних коштовностей України - філіалу Національного музею історії України [«Музейні читання»] (м. Київ, 17-18 грудня 1996 р.). - Київ, 1996. - С. 62-66.

69. Строкова Л. В. Василицький скарб з Черкащини із зібранні НМI України та його філіалу - Музею історичних коштовностей України / Л. В. Строкова // Матеріали ювілейної міжнародної науково-практичної конференції [«Музей на рубежі епох: минуле, сьогодення, перспективи»]. - Київ, 1999. - С. 75-76.

70. Харлампович К. - Науковий журнал українознавства «Україна». - Книга 36. - Київ: «Державне видавництво України», 1929. - С. 147-149.

71. Харламповіч П. Монэтныя скарбы, знойдзеныя ў Беларусі, у зборах Буларускага дзяржаўнага музэю / П. Харламповічь. - Мінск, 1929. - 343 с.

72. Шостопал А. В. Скарби Черкащини / А. В. Шостопал. - Черкаси: «Аадрощук П.С.», 2007. $-120 \mathrm{c}$.

73. Яушева-Омельянчик Р. М. Лисянський скарб монет (знахідка 1960 р.) // Тези доповідей наукової конференції Музею історичних коштовностей України - філіалу Національного музею історії України [«Музейні читання»] (м. Київ, грудень 1994). Київ, 1996. - С. 12-15.

74. Яушева-Омельянчик Р. М. Київський мюнц-кабінет у 1844-1864 роках / Р. М. ЯушеваОмельянчик // Тематичний збірник наукових праць [«Від першовитоків до сьогодення: із історії формування колекції музею»]. - Київ, 1995. - С. 174-188.

75. Яушева-Омельянчик Р. М. Монетні скарби музею / Р. М. Яушева-Омельянчик // Матеріали щорічної науково-практичної конференції [«Київ і кияни»]. - Вип. 2. - Київ: «Кий», 2002. - С. 95-96.

76. Яушева-Омельянчик Р. М. Скарб з с. Карапиші (з досвіду ідентифікації в НМІУ) / Р. М. Яушева-Омельянчик // Матеріали наукової конференції, присвяченої пам'яті видатного українського археолога і поета Б. М. Мозолевського (1936-1993) [«Музейні читання»] (Музей історичних коштовностей, лютий 1996 р.). -Київ, 1996. - С. 26-28.

\section{References}

1. Abramzon, M. G. (2007-2008) Korpus bosporskih kladov antichnyh monet [The corpus of the Bosporan hoards of the Antique coins]. (Vol. 1). - Simferopol'-Kerch', 2007-2008. [in Russian].

2. Aliev, R. (2014) Kollekcija monet Bahchisarajskogo zapovednika [The collection of the coins of the Bakhchisaraj reservation]. Muzejnij prostir, (2-12), 43-45. [in Russian].

3. Antonovich', V. B. (1900) Arheologicheskaja karta Volynskoj gubernii [Archeological map of the Volyn province] Moskva: Tipografija G. Lissnera i A. Greshelja. [in Russian].

4. Bakalets, O. (2007) Monetni skarby yak dzherelo vyvchennia [Coin hoards as the source of the study]. (Candidates thesis). Kyiv [in Ukrainian].

5. Beljashevskij, N. F. (1889) Monetnye klady Kievskoj gubernii [Coin treasures of the Kyiv province].Kiev. [in Russian].

6. Berg, D. Ja. (1974) Nekotorye klady monet XVI - XVII vv., najdennye na territorii USSR [Some treasures of coins of the XVI-XVII centuries, excavated in the territory of the USSR]. Numizmatika i Sfragistika, (5), 105-109. [in Russian].

7. Bielaia, O. (2013) Arkhivni dzherela pro monetni skarby Kyieva [Archival sources about the coins treasures of Kiev]. Arkheohrafichnyi shchorichnyk Pamiatky, (14), 189-194. [in Ukrainian].

8. Boiko-Haharin, A. S. (2014) Namysto iz shestyhroshovykamy, karbovanymy na lvivskomu monetnomu dvori, naidene u Vinnytskii oblasti [Necklace with six money casters hunched in Lviv mint is excavated in Vinnitsa region]. Lvivski numizmatychni zapysky, 10, 48-49. [in Ukrainian]. 
9. Bojko-Gagarin, A. S. (2014) K voprosu o vozmozhnosti chekanki getmanom Bogdanom Hmel'nickim fal'shivyh monet [On the question of the possibility of Hetman Bohdan Khmelnitsky has forging the coins].Proceedings of the Conference to the 419 annual of the hetman Bohdan Khmelnitsky's birth. VIII Bogdanivs'ki chitannja. (pp. 118-122). Cherkasi. [in Russian].

10. Bojko-Gagarin, A. S. (2016) Nahodki monet H-HII vekov po materialam ukrainskoj dorevoljucionnoj gazetnoj periodiki [Findings of coins of the X-XII centuries on the materials of the Ukrainian pre-revolutionary newspaper periodicals]. Proceedings of the Conference: IIIrd International Numismatic Conference: Jepoha vikingov $v$ Vostochnoj Evrope $v$ pamjatnikah numizmatiki VIII-XI vv.. (pp. 397-403). Sankt-Peterburg. [in Russian].

11. Bojko-Gagarin, A., Myzgin K. (2014) Koshelek polutornyh groshej Sigizmunda III s denariem Tita iz Zhitomirskoj oblasti [A wallet of Sigismund III with a denarii of Tita from Zhytomyr region]. Visnik Harkivs'kogo nacional'nogo universitetu im. V.N. Karazina. Serija Istorija. (Vol. 48), № 1117, 240-247. [in Russian].

12. Bojko-Gagarin, A.S. (2017) Fal'shivomonetnichestvo v Central'noj i Vostochnoj Evrope $v$ jepohu Srednevekov'ja i rannego Novogo vremeni [Coin counterfeiting in Central and Eastern Europe in the Middle Ages and Early New Time]. Kiev: Ukrainskaja konfederacija zhurnalistov. [in Russian].

13. Didenko, Ya. L. (2006) Serednovichni skarby v fondovomu zibranni Natsionalnoho istorykokulturnoho zapovidnyka Chyhyryn [Medieval treasures in the collection collection of the National Historical and Cultural Reservation of Chigirin]. Mohylianski chytannia Dolia muzeinykh zibran, (2), 43-48. [in Ukrainian].

14. Garbuz, B., Strizhakova, N. (1996) Pol'skie monety v Nacional'nom muzee istorii Ukrainy (istorija $i$ stan kollekcii) [Polish coins in the National Museum of History of Ukraine (history and state of the collection)] Proceedings of the Conference: Bilorus, Litwa, Polska, Ukraina. (pp. 21-30). Warszawa. [in Russian].

15. Gilevich, A. (1974) Klad hersono-vizantijskih monet iz okrugi Hersonesa [The vault of Kherson-Byzantine coins from the district of Chersonesos]. Numizmatika i sfragistika, 5, 9194, Kiev: Naukova dumka. [in Russian].

16. Golubickaja, A. A. (1998) Starinnye monety $v$ kollekcii DIM [Old coins from the Dnopropetrovsk historical museum collection]. Abstract of papers: Muzej i majbutnje. (pp. 5559). Dnipropetrovs'k: Poligrafist. [in Russian].

17. Goshkevich', V. I. (1903) Klady i drevnosti Hersonskoj gubernii. Kniga pervaja s hudozhestvennymi illjustracijami[Treasures and antiquities of the Kherson province. The book is the first with artistic illustrations]. Herson: Tipografija Juga. [in Russian].

18. Guleckij, D. (2015) Sostojanie metalla monet Gnivan'skogo klada [The metal consist of the coins of the Gnivan' treasure]. Rus', Litva, Orda v pamjatnikah numizmatiki $i$ sfragistiki, (1), 208-225. [in Russian].

19. Guleckij, D., Zajonchkovskij, Ju. (2015) Gnivan'skij klad nachala 2-j chetverti XV veka [Gnivansky treasure of the beginning of the 2 nd quarter of the 15th century]. Rus', Litva, Orda $v$ pamjatnikah numizmatiki i sfragistiki, (1), 163-207. [in Russian].

20. Harlampovich, P. (1929) Monjetnyja skarby, znojdzenyja w Belarusi, u zborah Bularuskaga dzjarzhawnaga muzjeju [Coin treasures excavated in Belarus in the collection of the Belarus State Museum]. Minsk. [in Belorusian].

21. Holysh, H. (2013) Numizmatychni doslidzhennia v suchasnii ukrainskii istoriohrafii: zdobutky, problemy, perspektyvy [Numismatic Studies in Contemporary Ukrainian Historiography: Achievements, Problems, Prospects]. Naukovi zapysky z ukrainskoi istorii, (33), 207-214. [in Ukrainian].

22. Iausheva-Omelianchyk, R. M. (1995) Kyivskyi miunts-kabinet u 1844-1864 rokakh [Kyiv Münster Cabinet in 1844-1864]. Abstract of papers: Vid pershovytokiv do sohodennia: iz istorii formuvannia kolektsii muzeiu. (pp. 174-188). Kyiv. [in Ukrainian].

23. Iausheva-Omelianchyk, R. M. (1996) Lysianskyi skarb monet (znakhidka 1960 r.) [The Lysyanka coin treasure (the discovery of 1960)]. Abstracts of papers of the Conference. Muzeini chytannia. (pp. 12-15). Kyiv. [in Ukrainian].

24. Iausheva-Omelianchyk, R. M. (1996) Skarb z s. Karapyshi ( $z$ dosvidu identyfikatsii v NMIU) [Treasure from Karapishi (from the experience of identification in NMHU)]. Proceedings of 
the Conference: Pamiati vydatnoho ukrainskoho arkheoloha i poeta B. M. Mozolevskoho (1936-1993). Muzeini chytannia. (pp. 26-28). Kyiv. [in Ukrainian].

25. Iausheva-Omelianchyk, R. M. (2002) Monetni skarby muzeiu [Coin treasures in museum]. Proceedings of the Conference: Kyiv i kyiany. (Vol. 2.). (pp. 95-96). Kyiv.[in Ukrainian].

26. Il'in, A. A. (1924) Topografija kladov drevnih russkih monet X-XI v. i monet udel'nogo perioda [Topography of the treasures of the ancient Russian coins of the 10th-11th centuries. and coins of the specific period]. Leningrad. [in Russian].

27. Kalkowski, T. (1974) Tysiac lat monety Polskiej [Thousand years of the coins of Poland]. Krakow [in Polish].

28. Klimovskij, S. I. (2005) Veshhevye klady XII - XIII kak indikator denezhnogo obrashhenija Juzhnoj Rusi [Treasures of the XII - XIII as an indicator of the monetary circulation of Southern Russia]. Sugdejskij sbornik, (2), 145-154. Kiev-Sudak. [in Russian].

29. Kotliar, M. F. (1971) Shukachi ta doslidnyky skarbiv [Seekers and researchers of treasures]. Kyiv, Naukova dumka. [in Ukrainian].

30. Kotliar, M. F. (1980) Monetni skarby Podillia yak istorychne dzherelo [Coin hoards of the Podillia region as the historical source]. Tezy dopovidei [Podillyas coin treasures as a historical source]. Proceedings of the Conference: $V$-a Podilska istoryko-kraieznavcha konferentsiia. (pp. 151-152). Kamianets-Podilskyi. [in Ukrainian].

31. Kotljar, N. F. (1970) Klad monet Vladimira Ol'gerdovicha [The treasure of Vladimir Olgerdovich's coins]. Numizmatika i jepigrafika, (88), 88-101. [in Russian].

32. Kotsur,V. (2016) Methodological issues of modern numismatic research: materials of black archeology and scientific research. Abstract of papers: Studia I Materialy Forum Numizmatyczne, Pieniadz I Mennice, (1), (pp. 5-9). [in English].

33. Kotsur, V. P. (2013) Aktualni napriamky ta orhanizatsiini zasady suchasnykh doslidzhen serednovichnoi numizmatyky $v$ Ukraini [Actual directions and the organizational principles of modern studies of medieval numismatics in Ukraine].Naukovi zapysky z ukrainskoi istorii, (33), 4. [in Ukrainian].

34. Kozlovskaja, E. I. (1965) Numizmaticheskaja kollekcija L'vovskogo istoricheskogo muzeja [Numismatic collection of the Lviv Historical Museum]. Numizmatika i sfragistika, (2), 152154. Kiev. [in Russian].

35. Kozubovskyi, H. A. (2012) Dani numizmatyky pro torhivelni shliakhy v Ukraini v seredyni $X I V$ st. [Numismatics data on trade routes in Ukraine in the middle of the XIV century.]. Arkheolohiia, (3), 75-82. [in Ukrainian].

36. Kropotkin, V. V. (1961) Klady rimskih monet na territorii SSSR [Treasures of Roman coins in the territory of the USSR]. Moskva. [in Russian].

37. Kuchynko, M., Kuchynko, Z. (2007) Davni ta serednovichni skarby Volyni [Ancient and Medieval treasures of Volyn]. Lutsk: Volynska knyha. [in Ukrainian].

38. Liamkin, V., Sherstiuk, V. (2011) Nevelykyi monetnyi skarb seredyny XVII st. $z$ Hadiachchyny[A small coin treasure in the middle of the XVII century from Gadyach]. Novi doslidzhennia pamiatok kozatskoi doby v Ukraini. (Vol. 2), (2), (pp. 17-21). Kyiv. UTOPIK. [in Ukrainian].

39. Ljaskoronskij, V. G. (1920) Rimskaja moneta v predelah Juzhnoj Rusi kak istoricheskij istochnik dlja drevnejshego perioda russkoj istorii [The Roman coin on the territory of the Southern Russia as a historical source for the most ancient period of Russian history]. Izvestija Istoriko-filologicheskogo instituta knjazja Bezborod'ko v Nezhine, (33), 1-16. [in Russian].

40. Malamuzh, O. (2000) Skarb monet XVII st. (iz fondiv NIKZ Chyhyryn) [Treasure coins of the XVII century. (from the funds of NHKR Chigirin)]. Novi doslidzhennia pamiatok kozatskoi doby $v$ Ukraini, (9), 74-81. [in Ukrainian].

41. Metelkin, N. V. (2005) Klady Ukrainy [Treasures of Ukraine]. Kiev: Antika. [in Russian].

42. Morawiecki,L. (2005) SkarbdelfinowzNikolajewa[The treasure with the dolphins from Nikolaew]Abstract of papers: Hroshovyi obih $i$ bankivska sprava $v$ Ukraini: mynule ta suchasnist, (pp. 9-15) Львів. [in Polish].

43. Mykulchyk, R., Slobodian, P., Didenko, Ye., Rak, T. (2012) Slovnyk-dovidnyk terminolohii muzeinytstva [Dictionary-Directory of terminology of museum science]. SlovoSvit, (15), 104. [in Ukrainian]. 
44. Novytskyi, Ya. (1997) Ostriv Khortytsia na Dnipri, yoho pryroda, istoriia, starozhytnosti [Khortytsya Island on the Dnieper, its nature, history, antiquities]. Starozhytnosti Pivdennoi Ukrainy, (1), 46-51. [in Ukrainian].

45. Oprysk, V., Rozhko, M. (2008) Skarb sribnykh monet z vul. Kleparkivskoi u m. Lvovi[Treasure of silver coins from the street. Kleparkivska in the city of Lviv]. Materialy $i$ doslidzhennia $z$ arkheolohii Prykarpattia i Volyni, (12), 393-406.

46. Orlik, V. M. (2013) Monety gosudarstva Tevtonskogo Ordena v Prussii v sostave denezhnyh $i$ denezhno-veshhevyh kladov, najdennyh na territorii Ukrainy [Coins of the state of the Teutonic Order in Prussia as part of monetary and monetary-material treasures found on the territory of Ukraine] Naukovi zapiski z ukrä̈n'koï istorii, (33), 39-45.[in Russian].

47. Orlik, V. M. (2015) Numizmaticheskie svidetel'stva torgovyh svjazej juzhnoruskih zemel' Velikogo knjazhestva Litovskogo s gorodami gosudarstva Tevtonskogo ordena v Prussii [Numismatic evidence of trade relations between the South Russian lands of the Grand Duchy of Lithuania and the cities of the state of the Teutonic Order in Prussia]. Proceedings of the Conference: Istorinès Lietuvos ir su ja susijusiu šaliu paveldas. (pp. 249-258). Vilnius. [in Russian].

48. Orlyk, V. M. (2013) Informatsiinyi potentsial WEB-resursiv u numizmatychnykh doslidzhenniakh (na prykladi monet derzhav Khrestonostsiv) [Information potential of WEBresources in numismatic studies (for example, the Crusader States coins)]. Proceedings of the Conference: Arkhivoznavchi ta dzhereloznavchi haluzi znan: problemy vzaiemodii na suchasnomu etapi. (pp. 129-133). Kyiv. [in Ukrainian].

49. Orlyk, W. (2015) Coins of the Teutonic Order contained in the hoard found in the suburbs of the city of Dubno of Rovenska region in March 2015. Pruthenia, Olsztyn, 10, 105-116.

50. Orlyk, V. (2016) A Coin Hoard of Pre-Reform Shillings of the Grand Master Michael Küchmeister von Sternberg Found in Chernihivschyna. Acta Archaeologica Lodziensia, 62, 93-97.

51. Orłyk, W. (2017) Rzadki wariant szelaga Zakonu Krzyżackiego z Teofipolskiego skarbu. [The rare variant of the schelag of Teutonic Order from the Teofipol hoard]. Biuletyn Numizmatyczny. 4 (388). 258-263.

52. Pioro, A. S., Gercen, A. G. (1974) Klad antoninianov iz s. Dolinnoe Krymskoj oblasti [Treasure of the Antoninianus from the village Dolinnoe in the Crimean region]. Numizmatika i sfragistika, (5), 81-90. [in Russian].

53. Popelnytska, O. (2004) Numizmatychno-rechovi skarby yak istorychne dzherelo (na prykladi skarbu XVI-XVII stolittia z sela Starosillia) [Numismatic and material treasures as a historical source (on the example of the treasure of the XVI-XVII centuries from the village Starosillya)]. Abstract of papers: Do 10-littia zasnuvannia viddilu spetsialnykh istorychnykh dystsyplin Instytutu istorii NAN Ukrainy. Spetsialni istorychni dystsypliny: pytannia teorii ta metodtyky. (11), Vol. 1, (pp. 204-207). Kyiv. [in Ukrainian].

54. Potin, V. M. (1962) Nahodki zapadnoevropejskih monet na territorii drevnej Rusi $i$ drevnerusskie poselenija [Finds of Western European coins on the territory of ancient Rus and ancient settlements]. Numizmatika i jepigrafika. Moskva: Izdatel'stvo Akademii nauk SSSR, (3), 183-212. [in Russian].

55. Povorozniuk, K. (2010) Skarby monet XVI st. z fondiv Khmelnytskoho oblasnoho kraieznavchoho mиzeiu [Treasures of coins of the XVI century from the collection of the Khmelnytsky Regional Museum]. Proceedings of the Conference: Novi doslidzhennia pamiatok kozatskoi doby v Ukraini. (19), 114-117, Kyiv. [in Ukrainian].

56. Rjabcevich', V. N. (1963) Monetnye klady XVII i pervoj chetverti XVIII v. naterritorii Chernigovo-Severskoj zemli i Vostochnoj Belorussii [Coins of the XVII and the first quarter of the XVIII century. on the territory of the Chernigov-Seversky land and East Belorussia]. Numizmatika i sfragistika. Kiev: Izdatel'stvo Akademii nauk Ukrainskoj SSSR, (Vol. 1). 152202. [in Russian].

57. Rjabcevich, V. N. (1998) Lysjankovskij i Poltavskij, Putivl'skij i Sevskij monetnye dvory [Lysyanskiy and Poltava, Putivlsky and Sevsky mints]. Proceedings of the Conference: Numizmatycznej Mennice Miedzy Baltykiem a morzem Czarnym - wspolnota dziejow. (pp. 175-186). Warszawa. [in Russian]. 
The Ukrainian Numismatic Annual, Issue 1.

58. Sementovskij, N. M. (1857) Zaporozhskaja rukopis' ukazyvajushhaja v kakih imenno mestah $i$ kakie sokryty klady gajdamakami $i$ mestnymi zhiteljami [The Zaporizhzhya manuscript indicating in which places and what treasures haidamaks and local residents have had hidden]. Kiev: Tipografija A. Gammershmidta. [in Russian].

59. Shostopal, A. V. (2007) Skarby Cherkashchyny [Cherkassy treasures]. Cherkasy: Aadroshchuk P. S. [in Ukrainian].

60. Sinchuk, I. I. (2000) Oboly Teshina v kladah Ukrainy [Obols of the duchy of Teschin in the treasures of Ukraine]. Numizmatika, (1), 53-63. [in Russian].

61. Strashkevich, K. (1866) Klady, rassmotrenye $v$ minc-kabinete universiteta sv. Vladimira $s$ 1818 po $1866 \mathrm{gg}$. [Treasures, reviewed in the Mint-office of the University of St. Vladimir from 1818 to 1866 years.]. Universitetskie izvestija. [in Russian].

62. Strilets, M. S. (1989) Kyivskyi monetnyi skarb iz vul. Artema (novi nadkhodzhennia) [Kiev coin treasure from the street. Artem (new incomes)]. Abstract of papers: Muzei i suchasnist. (pp. 38-47). Kyiv. [in Ukrainian].

63. Strilets, M. S. (1996) Lebedynskyi monetno-rechovyi skarb - sensatsiina znakhidka 1996 roku [Lebedinsky coin and material treasure - a sensational discovery of 1996]. Proceedings of the Conference: Muzeini chytannia. (pp. 62-66). Kyiv. [in Ukrainian].

64. Strokova, L. V. (1999) Vasylytskyi skarb z Cherkashchyny iz zibranni NMI Ukrainy ta yoho filialu - Muzeiu istorychnykh koshtovnostei Ukrainy [Vasylitsky treasure from Cherkassy region from the meeting of the NMI of Ukraine and its branch - Museum of the Historical Treasures of Ukraine]. Proceedings of the Conference: Muzei na rubezhi epokh: mynule, sohodennia, perspektyvy. (pp. 75-76). Kyiv. [in Ukrainian].

65. Zajonchkovskij, Ju. V. (2015) Klad dzhuchidskih dangov XV veka s berega reki Severskij Donec [The treasure of the Djuchid dangas of the 15th century from the banks of the Seversky Donets river]. Rus', Litva, Orda v pamjatnikah numizmatiki i sfragistiki, (1), 226-241. [in Russian].

66. Zraziuk, Z. O. (2009) Monetni skarby pershoi polovyny XVII st. z terytorii Pravoberezhnoi Ukrainy (suchasna terytoriia Kyivskoi ta Zhytomyrskoi oblasti) [Coin treasures of the first half of the XVII century from the territory of Right-bank Ukraine (modern territory of Kiev and Zhytomyr region)]. Abstract of papers: Natsionalnomu muzeiu istorii Ukrainy - 110. (Vol. 1), (pp. 158-168). Kyiv. [in Ukrainian].

67. Zvarich, V. V. (1980) Numizmaticheskij slovar' [Numismatic vocabulary]. L'vov: Vishha Shkola. [in Russian]. 